\title{
Stability and Specific Substrate of Lipase from Microbes in Coconut Pulp Media
}

\author{
I. Dewa Gde Mayun Permana* and Ni Luh Ari Yusasrini
}

Food Science and Technology Study Program, Faculty of Agricultural Technology, Udayana University, Bukit Jimbaran Badung, Bali, Indonesia

*Corresponding author

\section{Keywords}

Stability, Specific substrate, lipase, microbe, coconut pulp

\section{Article Info}

Accepted:

12 April 2021

Available Online:

10 May 2021
One source of lipase that is considered potential is from microbes because microbes can multiply rapidly. The advantage of microbes is being able to adapt quickly to the environment, including growing media. Coconut pulp still contains fat with lauric acid as the dominant fatty acid. The purpose of this study was to obtain temperature and $\mathrm{pH}$ stability and lipase specific substrate from microbes grown on coconut pulp media. To achieve this goal a partial purification of lipase was carried out with ammonium sulfate. The obtained lipases were tested for temperature and $\mathrm{pH}$ stability by hydrolysis activity. Specific substrates were determined by testing esterification activity using several types of fatty acids. The results showed that at the saturation level of $60 \%$ ammonium sulfate produced lipase with the highest level of activity. The resulting lipase has a stability of more than $90 \%$ at $40^{\circ} \mathrm{C}$ and $\mathrm{pH} 6$ is the most stable activity. Substrates that show high activity are lauric acid and oleic acid.

\section{Introduction}

The need for lipase in the world continues to increase and the price is expensive, especially for lipases that have specific properties on the substrate or regiospecific (1) and (2). Lipases catalyze the breakdown of ester bonds in fat to produce fatty acids and glycerol (3). Lipase is also able to catalyze the esterification reaction at low water levels (4). Lipase is much needed for research and industrial needs such as food, pharmaceuticals, cosmetics, detergents and others so that it becomes an opportunity for commercial production of lipase. According to Ferraz et al., (5) lipase has a different character so for its application it is necessary to know the character of the lipase. The most influential factor in its application is its stability against temperature and $\mathrm{pH}$. One very potential source of lipase is microbes because microbes can be bred quickly. Bacteria and molds are widely used as a source of lipase, 
such as Aspergillus niger, Candida cylendracea, Mucor miehei, Penicillium camemertii and Pseudomonas cepacia. Lipases from microbes usually have a high affinity for the dominant fatty acids in the growth media so that specific lipases will be produced. Lipases from Aspergillus niger MYA have high affinity for long chain fatty acids (C18) (6), whereas pancreatic lipases prefer PUFA. Lipases from Candida rugosa and Thermomyces lanuginose have higher activity than pancreatic lipases (7).

Coconut pulp has been considered as food processing waste after extracting coconut milk and is generally used as animal feed. In addition to utilizing coconut milk, coconuts are generally used as a source of vegetable fat. According to Kwon et al., (8) mature coconut meat which has a water content of $40.9 \%$, has a protein content of $3.8 \%$ and fat of $35.2 \%$. Marina et al., (9) conducted an analysis of commercial coconut oil sold in Malaysia and Indonesia. Lauric acid (C-12) is a fatty acid with the largest proportion ranging from 46.64 to $48.03 \%$, followed by myristic acid (C14) $16.23-18.90 \%$. If the coconut pulp is used as a medium for microbial growth, it is hoped that lipase can be isolated from microbes that have a specific substrate. The purpose of this study was to determine the temperature and $\mathrm{pH}$ stability and lipase specific substrate from microbes that grow on coconut pulp media.

\section{Materials and Methods}

\section{Research Stages}

The order of research to be carried out in outline is as follows

The obtained lipase is partially purified using ammonium sulfate.

The partially purified lipase was tested for its esterification activity using several types of fatty acids with glycerol to determine its specific substrate.

Stability of lipase temperature and $\mathrm{pH}$ is determined by testing the lipase hydrolysis activity at various temperatures and $\mathrm{pH}$.

\section{Time and Place}

The study was conducted by the laboratory of the Faculty of Agricultural Technology, UPT Integrated Laboratory of Biotechnology and Bioscience and Analytical Chemistry Laboratory of Udayana University, Bali. The time for conducting research will be from June 2019 to October 2019

\section{Raw Materials and Chemicals}

Coconut pulp is made from coconuts taken from a traditional market in Denpasar, Bali Province. Chemicals such as isooctan, $\mathrm{Na}_{2} \mathrm{HPO}_{4}, \quad \mathrm{NaH}_{2} \mathrm{PO}_{4}$, ammonium sulfate, glycerol, EDTA, Cu-acetate, pyridine from Merck Germany. Extremely high purity standard chemicals such as olive oil, fatty acid kits from Sigma Co., St. Louis, MO, USA.

\section{Tools}

Mortal, digital pH meter (TOA HM 605), magnetic stirrer, centrifuge (Herolap, Germany), water bath shaker (Shel-Lab), test tube, vortex, thin cotton cloth, Analytical Balance (Sartorius), Spectrophotometer UVVis (Genesys 10S UV-Vis),

\section{Research procedure}

\section{Microbial growth on coconut pulp}

Grated coconut flesh is then extracted to take coconut milk to obtain coconut pulp. Coconut pulp added tempe then covered with gauze and left at room temperature for 5 days. Coconut pulp that has been overgrown with microbes is extracted to obtain lipase 
Preparation of modified enzyme extraction (10)

The enzyme was isolated at $4^{\circ} \mathrm{C}$ for all experiments carried out. The coconut palm pulp is homogenized for 10 minutes in $0.15 \mathrm{M}$ phosphate buffer consisting of $0.6 \mathrm{M}$ sucrose, $1 \mathrm{mM}$ EDTA $10 \mathrm{mM} \mathrm{KCl}$ and $1 \mathrm{mM} \mathrm{MgCl} 2$. Homogenate is centrifuged for 40 minutes at $10,000 \mathrm{rpm}$. The supernatant layer is taken for testing dissolved protein, hydrolysis activity, lipase esterification

\section{Lipase Fractionation with Ammonium sulfate}

Fractionation of lipases with ammonium sulfate was carried out by following the Doonan method (11).

Ammonium sulfate is added to the active extract with varying concentrations (20-40\%, $40-60 \%$ and $60-80 \%$ ). The addition of ammonium sulfate starts from the lowest concentration of $20 \%$. Extract as much as 100 $\mathrm{ml}$ in a stirer at $4^{0} \mathrm{C}$ and then centrifuged 5000 $\mathrm{g}$ for 30 minutes. The precipitate is separated and the supernatant is added to the ammonium sulfate to a saturation concentration of $40 \%$. Centrifuged $5000 \mathrm{~g}$ for 30 minutes, the supernatant was saturated again with ammonium sulfate to $60 \%$. Return centrifuged for 30 minutes at $5000 \mathrm{~g}$. The supernatant was separated and saturated again at a concentration of $80 \%$. Then centrifuged at $5000 \mathrm{~g}$ for 30 minutes. The pellet and the supernatant from the results of each concentration were tested for their activity by the method of Marseno (1998) (12) and dissolved protein by the Lowry-Folin method(13).

\section{Lipase Hydrolysis Activity (12)}

$60 \%$ olive oil in isooktan added $10 \%$ crude lipase, divortex for 5 minutes. incubated at $37^{\circ} \mathrm{C}$ for 1 hour. After the incubation is immediately put into ice for a few moments. Samples were taken $5 \mathrm{ml}$ and added $0.7 \mathrm{~mL}$ $\mathrm{Cu}$ pyridine acetate $\mathrm{pH}$ 6, gojok solution for 90 seconds by hand. After that the solution was centrifuged at $2000 \mathrm{rpm}$ for 10 minutes, then absorbed at $715 \mathrm{~nm}$ wavelength

\section{Lipase Specific Substrate}

Crude lipase concentration of $5 \%$ plus 60 $\mu \mathrm{mol} / \mathrm{ml}$ various fatty acids (myristic, lauric, oleic, palmitic, stearic) shaked for 10 minutes. Glycerol $20 \mu \mathrm{mol} / \mathrm{ml}$ is added to the mixture as soon as possible and incubated at $40^{\circ} \mathrm{C}$ for 24 hours. After the incubation is immediately put into ice for a few moments.

Furthermore the remaining fatty acids were analyzed using the method of Marseno, et.al (12) samples were taken $300 \mu \mathrm{L}$ and added 2.7 $\mathrm{mL}$ isooktan and $0.6 \mathrm{~mL} \mathrm{Cu}$ pyridine acetate $\mathrm{pH} 6$, corner the solution for 90 seconds by hand.

After that the solution was centrifuged at a speed of $2000 \mathrm{rpm}$ for 5 minutes, then absorbed at a wavelength of $715 \mathrm{~nm}$. The highest amount of fatty acid that is etched shows the specific substrate.

\section{Temperature Stability Test}

Temperature stability is determined by heating the lipase solution at a temperature variation of $30,40,50$ and $60^{\circ} \mathrm{C}$ for 1 hour then cooled. Residual activity is measured by the same method at its optimum temperature conditions. The reaction time for activity testing is done for 1 hour.

\section{pH Stability Test}

The $\mathrm{pH}$ stability test was carried out following the method of Mayordomo et.al (14). $0.15 \mathrm{ml}$ lipase solution plus $0.15 \mathrm{M}$ universal buffer with a $\mathrm{pH}$ of $4-10$ was $1.35 \mathrm{ml}$ and was incubated for 30 minutes. Furthermore lipase 
hydrolysis activity was tested under optimum $\mathrm{pH}$ conditions.

\section{Results and Discussion}

Lipase fractionation with ammonium sulfate

The results of lipase precipitation from microbes on coconut pulp media using ammonium sulfate solution at varying concentrations resulted in different specific activities and recovery (Table 1 ).

The highest specific activity was obtained at a $60 \%$ concentration level. Likewise the highest recovery rate was obtained at $60 \%$ ammonium sulfate concentration. Based on the results of specific activities and recovery of lipase, the precipitation results were chosen at $40-60 \%$ ammonium sulfate concentration for further testing.

\section{Temperature Stability}

The results of microbial lipase stability test on coconut pulp in the temperature range of 30$55^{\circ} \mathrm{C}$ with an interval of $5{ }^{\circ} \mathrm{C}$ showed that up to $40^{\circ} \mathrm{C}$ was still stable (Table 2). Lipase activity at a temperature of $45^{\circ} \mathrm{C}$ has decreased and at a temperature of $55^{\circ} \mathrm{C}$ only $72.27 \%$, meaning that microbial lipase on coconut pulp has stability at a temperature of $40^{\circ} \mathrm{C}$. Illanes et al., (2008) (15) state that high temperatures can cause the breakdown of non-peptide bonds to break so that the lipase structure changes resulting in decreased lipase activity. The stability of microbial lipase is similar to that of peanut in the temperature of $40^{\circ} \mathrm{C}$, its activity is still stable, while at $50^{\circ} \mathrm{C}$ there is a drastic decrease in activity (Sanders and Pattee, 1975).(16)

Table.1 Specific Activities and Recovery of Lipase Resulting from Precipitation with Ammonium Sulfate

\begin{tabular}{|c|c|c|c|c|c|}
\hline $\begin{array}{c}\text { Ammonium } \\
\text { Sulfate } \\
\text { concentration }\end{array}$ & $\begin{array}{c}\text { Activity } \\
\text { (U/ml) }\end{array}$ & $\begin{array}{c}\text { Protein } \\
\text { content } \\
(\mathbf{m g} / \mathbf{m l})\end{array}$ & $\begin{array}{c}\text { Specific } \\
\text { activity (U/mg } \\
\text { protein) }\end{array}$ & $\begin{array}{c}\text { Total } \\
\text { Activity (U) }\end{array}$ & $\begin{array}{c}\text { Recovery } \\
(\mathbf{\%})\end{array}$ \\
\hline $\mathbf{0}$ & $0.542 \pm$ & $2.321 \pm$ & $0.241 \pm 0.069$ & $75.406 \pm$ & $100 \pm 000$ \\
& 0.034 & 0.527 & & 5.625 & \\
\hline $\mathbf{2 0}$ & $0.473 \pm$ & $0.559 \pm$ & $0.846 \pm 0.016$ & $1.419 \pm 0.173$ & $1.884 \pm 0.028$ \\
& 0.006 & 0.081 & & & \\
\hline $\mathbf{4 0}$ & $0.482 \pm 0.03$ & $0.363 \pm$ & $1.333 \pm 0.083$ & $1.447 \pm 0.010$ & $1.939 \pm 0.286$ \\
\hline $\mathbf{6 0}$ & $0.741 \pm$ & $0.384 \pm$ & $2.139 \pm 0.102$ & $4.03 \pm 0.073$ & $5.398 \pm 0.664$ \\
& 0.108 & 0.147 & & & \\
\hline $\mathbf{8 0}$ & $0.314 \pm$ & $0.955 \pm$ & $0.388 \pm 0.235$ & $1.568 \pm 0.179$ & $2.117 \pm 0.536$ \\
\hline
\end{tabular}


Table.2 Lipase Activity of Ammonium Sulfate Precipitation from 40-60\% in Temperature Stability Test

\begin{tabular}{|c|c|c|}
\hline $\begin{array}{c}\text { Temperature } \\
\left({ }^{\mathbf{C}} \mathbf{C}\right)\end{array}$ & Activity (U/ml) & Persen Activity \\
\hline $\mathbf{3 0}$ & $0.988 \pm 0.001$ & $99.62 \pm 0.317$ \\
\hline $\mathbf{3 5}$ & $0.984 \pm 0.007$ & $99.23 \pm 0.231$ \\
\hline $\mathbf{4 0}$ & $0.972 \pm 0.009$ & $97.99 \pm 0.455$ \\
\hline $\mathbf{4 5}$ & $0.884 \pm 0.055$ & $89.09 \pm 5.193$ \\
\hline $\mathbf{5 0}$ & $0.858 \pm 0.062$ & $86.46 \pm 5.860$ \\
\hline $\mathbf{5 5}$ & $0.717 \pm 0.036$ & $72.27 \pm 3.916$ \\
\hline Control & $0.992 \pm 0.004$ & $100 \pm 0.003$ \\
\hline
\end{tabular}

Table.3 Lipase Activity of Ammonium Sulfate Precipitation from 40-60\% in pH Stability test

\begin{tabular}{|c|c|c|}
\hline $\mathbf{p H}$ & Aktivity $(\mathbf{U} / \mathbf{m l})$ & Persen Activity \\
\hline $\mathbf{3}$ & $1.666 \pm 0.068$ & $69.428 \pm 0.549$ \\
\hline $\mathbf{4}$ & $2.065 \pm 0.047$ & $86.067 \pm 0.908$ \\
\hline $\mathbf{5}$ & $2.277 \pm 0.072$ & $94.893 \pm 0.147$ \\
\hline $\mathbf{6}$ & $2.387 \pm 0.032$ & $99.503 \pm 1.957$ \\
\hline $\mathbf{7}$ & $2.231 \pm 0.101$ & $92.955 \pm 1.121$ \\
\hline $\mathbf{8}$ & $1.809 \pm 0.018$ & $75.456 \pm 3.265$ \\
\hline Optimum & $2.399 \pm 0.079$ & $100.003 \pm 0.017$ \\
\hline
\end{tabular}

Table.4 Lipase Activity Resulting from Ammonium Sulfate Precipitation of 40-60\% in the Substrate test

\begin{tabular}{|c|c|}
\hline Fatty Acid & Esterification Activity \\
\hline C 8 : 0 & $0.086 \pm 0.011$ \\
\hline C12 : 0 & $0.277 \pm 0.011$ \\
\hline C14 : 0 & $0.152 \pm 0.028$ \\
\hline C16 : 0 & $0.037 \pm 0.005$ \\
\hline C18 : 0 $18: 1$ & $0.044 \pm 0.006$ \\
\hline
\end{tabular}

\section{pH Stability}

The stability of microbial lipase on coconut pulp media to $\mathrm{pH}$ was carried out in the $\mathrm{pH}$ range 3-8.

The difference in $\mathrm{pH}$ is greater than the optimum $\mathrm{pH}$ causing lower stability (Table 3 ). At $\mathrm{pH} 6$ the activity is the most stable, this corresponds to the optimum $\mathrm{pH}$. The activity is relatively stable in the $\mathrm{pH}$ range 5-7, while at $\mathrm{pH} 4$ and 8 there is a decrease in activity of about $14 \%$.

At extreme $\mathrm{pH}$ it causes large structural changes making it difficult to return to the original structure after being returned to its optimum $\mathrm{pH}$. 


\section{Specific Substrate}

The results of esterification activity testing using various fatty acids obtained the highest activity in lauric acid and followed by oleic acid (Table 4). This means that microbial lipase is not specific to the length of the fatty acid chain but more specific to the type of fatty acid. This is in accordance with the types of fatty acids in coconut oil which are lauric acid and followed by oleic acid. According to Lotti and Alberghina (2007) (17), the selective nature of lipase to the substrate is strongly influenced by the shape and size of the pocket (Hole) on its active side.

The results of microbial lipase precipitation were obtained at a concentration of ammonium sulfate 60 percent, has a temperature stability of $40^{\circ} \mathrm{C}$ and a $\mathrm{pH}$ of 6 . Lipase has specific properties for the types of fatty acids namely lauric and oleic acids.

\section{Acknowledgement}

This research was carried out with the help of DIPA PNBP Udayana University TA-2019 through LPPM Unud with the Letter of Appointment for Research Implementation. Number: 1558 / UN14.2.12.II / PN / 2019, April 22, 2019

\section{References}

1. Weete, J. D. 2002. Microbial Lipases. In: Food Lipids: Chemistry, Nutrition, and Biotechnology, edited by Akoh, C.C dan Min, D.B, Marcel Dekker, New York. pp:813-838

2. Chandler, I. C. 2001. Determining the Regioselectivity of Immobilized Lipases in Triacylglycerol Acidolysis Reactions. JAOCS. 78:737-742.

3. Paiva, A. L., Balcao, V. M., Malcata, F. X. 2000. Kinetics and mechanisms of Reactions Catalyzed by Immobilized
Lipases. Journal of Enzyme and Microbial Technology. 27: 187-204.

4. Willis, W. M. and A. G. Marangoni. 2002. Enzymatic Interesterification, In: Food Lipids: Chemistry, Nutrition, and Biotechnology, edited by Akoh, C. C dan Min, D. B, Marcel Dekker, New York

5. Ferraz, L. R., D. S. Oliveira, M. F. Silva, E. R., M. DiLuccio, J. V. Oliveira, D. deOliveira, dan H. Treichel. 2012. Production and Partial Characterization of Multifunctional Lipases by Sporobolomyces ruberrimus using Soybean meal, Rice meal and Sugarcane bagasse as Substrates. Biocatalysis and Agricultural Biotechnology. $1: 243-252$

6. Romero, C. M., L. M. Pera, F. L., C. Vallejos, G. Castro, dan M. D. Baigori. 2012. Purification of Anorganic Solventtolerant Lipase from Aspergillus niger MYA 135 and Its Application in Ester Synthesis. Biocatalysis and Agricultural Biotechnology. $1: 25-31$.

7. Freitas, L., Bueno, T., Perez, V. H.,Santos, J. C. dandeCastro, H.F. (2007). Enzymatic hydrolysis of soybean oil using lipase from different sources to yield concentrated of polyunsaturated fatty acids. World Journal Microbiol Biotechnol.23: 1725-1731.

8. Kwon, K. S., Bae, D., Park, K. H. dan Rhee, K. C. 1996. Aqueous extraction and membrane technique improve coconut protein concentrate functionality. Journal of Food Science.61 (4): 753-756.

9. Marina, A. M., Che Man, Y. B. danNazimah, S. A. H. 2009. Chemical properties of virgin coconut oil. Journal of American Oil Chemists' Society86:301-307

10. Abigor, R. D., Uadia, P. O., Foglia, T. A., Hass, M. J., Scott, K. dan Savary, B.J.2002. Partial and Properties of Lipase from Germaning Seeds of Jatropha curcas L. JAOC. 79: 1123-1126.

11. Doonan, S. 1996. Bulk Purification by Fractinational Precipitation. Dalam : Protein Purification Protocols. Doonan 
(Ed.) Humana Press Inc. Totowa, New Jersey.

12. Marsena, D. W. Indarti, R., dan Ohta.1999. A simplied Method for Determination of Free Fatty Acids for Soluble and Immobilized Lipase Assay. Indonesian Food and Nutrion Progress. 5: 79-83.

13. Sudarmadji, S., B. Haryono, dan Suhardi.1984. Prosedur Analisa untuk Bahan Makanan dan Pertanian. Liberty, Yogyakarta.

14. Mayordomo, I., F. Randez-Gil, dan J. A. Prieto. 2000. Isolation, Purification and Characterization of a Cold-Active Lipase from Aspergillus nidulans. J. Agric Chem. 48 (1).

15. Illanes, A., C. Altamirano dan L. Wilson L. 2008. Homogeneous Enzyme Kinetics. Dalam : Enzyme Biocatalysis Principles and Applications. Illanes (Ed.). Springer.

16. Sanders, T. H. dan H. E. Pattee. 1975. Peanut Alkaline Lipase. Lipids. 10 (1).

17. Lotti, M. and L. Alberghina. 2007. Lipases : Molekular Structure and Function. In Industrial Enzym : Structure, Function and Application. (Polaina, J and MacCabe, Ed.). Springer, Netherland.

\section{How to cite this article:}

Dewa Gde Mayun Permana, I. and Ni Luh Ari Yusasrini. 2021. Stability and Specific Substrate of Lipase from Microbes in Coconut Pulp Media. Int.J.Curr.Microbiol.App.Sci. 10(05): 429435. doi: https://doi.org/10.20546/ijcmas.2021.1005.050 